\title{
Analysis of Visitor Satisfaction with Public Transport in Munich
}

\author{
Diem-Trinh Le-Klähn \\ Technische Universität München \\ C. Michael Hall \\ University of Canterbury, New Zealand \\ Regine Gerike \\ University of Natural Resources and Life Sciences, Vienna
}

\begin{abstract}
This study investigates the use of public transport by visitors in the city of Munich, Germany. It seeks to understand how visitors perceive public transport services and which factors influence their level of satisfaction. Data were collected from a survey in April and May 2012 with a random sample at selected tourist sites in Munich. Factor analysis resulted in four different service dimensions - traveling comfort, service quality, accessibility and additional features. Visitors were found to be generally satisfied with public transport services in Munich, and their perceptions are independent from most factors.
\end{abstract}

\section{Introduction}

Among various modes of land transport (Duval 2007; Page 2011), the use of public transport (or mass transit, public transit, public transportation) has multiple environmental, social, and economical benefits (Litman 2011; Gwilliam 2008; Litman 2007). However, most research on public transport focuses on local users rather than the public transport needs of visitors. Yet, given the significance of the visitor economy for many urban areas, including resort areas, understanding and facilitating tourist use of public transport is becoming of increased importance. Although car use is the most popular visitor transport mode (Regnerus, Beunen, and Jaarsma 2007; Guiver et al. 2007), congestion, pollution, traffic problems, and demands for sustainable transport practices have led to a renewed focus on the importance of public transportation in urban tourism development. However, encouraging a modal shift is not an easy task (Redman et al. 2013; Dickinson, Robbins, and Fletcher 2009; Lumsdon, Downward, and Rhoden 2006). To promote public transport use, whether to visitors or to local users, it is critical to have an effective and efficient system. Specifically, transport services should be demand-oriented, and a 
good knowledge of customer behavior is thus of great importance (Gronau and Kagermeier 2007).

This paper examines the use of public transport by visitors in the city of Munich, Germany. Public transport mentioned in this study refers primarily to rail (train, tram, subway) and buses. It explains how visitors evaluate public transport services and what factors influence their perception. The most important service aspects determining overall satisfaction are also discussed. In addition, recommendations for public transport management and operator are offered.

\section{Customer Satisfaction with Public Transport}

Measuring customer satisfaction with public transport services is an important topic in transportation research and practice. To improve services and increase the number of customers, providers need to understand how much customer expectations have actually been fulfilled. Customer surveys are critical, as they provide transport operators with valuable information such as what aspects are important for customers and what they are particular happy or unhappy about.

Felleson and Friman (2008) reported on an annual transnational public transport customer satisfaction study in eight European cities (Stockholm, Barcelona, Copenhagen, Geneva, Helsinki, Vienna, Berlin, Manchester, and Oslo). Four satisfaction dimensions were delineated from a factor analysis of 17 attribute-related statements: system, comfort, staff, and safety. However, the results were not consistent in all cities, meaning that public transport services were perceived differently. Several factors contribute to the variation of customer perceptions, including those related to management (how the services were provided) and personal group (culture and tradition).

In her study of customer satisfaction with public transport in Indonesia, Budiono (2009) identified two groups of service attribute. The "soft quality" factor includes security issues and comfort, and the "functionality quality" consists of frequency, travel time, punctuality, and time, with the latter being the more influential on levels of the customer satisfaction. In contrast, Tyrinopoulos and Antoniou (2008) emphasized the differences of customer perception between different transit operators due to their specific characteristics and service conditions. In general, the most important satisfaction attributes across transit operators are service frequency, vehicle cleanliness, waiting conditions, transfer distance, and network coverage. However, the results are varied among transit systems. For instance, vehicle cleanliness, staff behavior, and ticketing systems are the most important attributes for metro (subway) operators. In the case of bus operators, customers stressed service frequency, vehicle cleanliness, and network coverage. A well-coordinated and reliable transportation environment is strongly preferred by all users. In their study of Swedish residents in Göteborg, Friman, Edvardsson, and Gärling (2001), and Friman and Gärling (2001) indicated a relationship between frequency of negative critical incidents and satisfaction with public transport (low frequency led to increased satisfaction). Moreover, the authors believed staff behavior was of significant importance in customer perception, along with service reliability, simplicity of information and design. In contrast, Lai and Chen (2011) suggested that service quality and perceived value should 
receive greatest attention in improving customer satisfaction, whereas Eboli and Mazzula (2007) stressed the role of service planning and reliability.

Diana (2012) examined the degree of satisfaction of multimodal travelers with public transport services in Italy. Nine service aspects were measured. The author found that satisfaction and frequency of use of urban transit are not correlated. Public transport received greatest use in city centers, followed by towns of above 50,000 inhabitants. However, satisfaction levels tended to be highest in smaller towns and lowest in metropolitan areas.

A study of travel mode switching in Switzerland indicated that satisfaction and attitudes were related to behavior and habits (Abou-Zeid et al. 2012). Those who switched to public transport tended to be more satisfied than those who did not. Furthermore, as is often found in customer satisfaction studies (Song et al. 2012; Tribe and Snaith 1998), expectation is also a factor influencing satisfaction with public transportation experience. Additionally, public transport satisfaction is affected by travel time: longer travel times result in lower levels of satisfaction (Gorter, Nijkamp, and Vork 2000). Similarly, crowded or unreliable services and long wait times often make customers less satisfied (Cantwell, Caulfield, and O'Mahony 2009).

These studies have provided significant insights into how passengers evaluate public transport performance. However, they targeted local residents rather than visitor users of public transport. Nevertheless, tourists may make up a substantial proportion of public transport use at urban destinations, and their behavior, expectations, and perceptions of public transport performance potentially are considerably different from those of local users and worthy of separate investigation. The following sections describe the use of public transport by tourists at the destinations.

\section{Tourist Use of Public Transport}

Tourists exhibit diverse perceptions and attitudes towards transport (Dallen 2007). Their satisfaction with transport is influenced by several factors. It was found that visitors differ significantly from local users in terms of their needs and use of public transport (Kinsella and Caulfield 2011). Newcomers to the city of Dublin were more concerned with the provision of information and reliability of service and placed less emphasis on traditional aspects of public transport such as service quality and safety. By contrast, Dubliners considered punctuality, frequency, and waiting times as most important. In addition, tourists are also different from local users in their information search behavior: they require more information and use different sources (Thompson 2004). Specifically, information centers, word-of-mouth, attraction leaflets, the Internet, and hotel reception are common information sources for tourists.

Stradling et al. (2007) argued that age and frequency of use are the most influential on tourist satisfaction with transport, whereas factors such as household income, car availability, and gender are less significant. A study in Turkey and Mallorca, however, identified cultural background as an important dimension (Kozak 2001). For example, British tourists are generally more satisfied with local transport services during their summer 
holidays than German tourists. Other influences on satisfaction include word-of-mouth communication, purchase intention, and complaining behavior (Kim and Lee 2011).

In the UK, public transport (mainly buses) in rural areas generally received relatively high satisfaction levels in service dimensions such as comfort, cleanliness, information, and driver helpfulness. On the other hand, there were also complaints about poor service delivery, unreliability, poor information, bad driving or inferior vehicles, and, above all, frequency of services (Guiver et al. 2007).

Public transport is considered an additional tourism product, which adds to the total tourist experience (Duval 2007). Thompson and Schofield (2007) examined the relationship between public transport performance and destination satisfaction. Their study of tourists in Greater Manchester showed that how tourists evaluate public transport performance could slightly influence their satisfaction with the destination. The authors emphasized the importance of public transport's ease-of-use, as it has great impact on satisfaction than efficiency and safety. However, the study is limited to public transport at one place (Greater Manchester) and only to overseas visitors. Furthermore, the paper has a focus on the public transport and destination satisfaction relationship, whereas other influences were, unfortunately, neglected. There is, therefore, a need to understand tourist perceptions of public transport in another context and with extended dimensions. It is important to explore not only customer satisfaction but also influencing factors and their impacts on customer perception. A study on tourist use of public transport in Munich is of significance to this area.

\section{Public Transport in Munich}

Munich is the capital of the state of Bavaria and the third largest city in Germany. A commercial, industrial, and cultural center, Munich is the second most visited city in Germany (after Berlin), with 5.2 million foreign visitors in 2010 (German National Tourist Board 2011). Along with its long history and rich culture, the city also boasts several remarkable arts museums, historical sites, and festivals that attract millions of tourist arrivals every year, especially during Oktoberfest. As a growing city with increasing numbers of tourists, having a well-developed public transport system is part of the City's forward-looking transport policy, which emphasized an efficient transport system as pivotal for the proper functioning of a large modern city (City of Munich 2005a, 2005b).

Munich has a well-developed and extensive traffic and public transport network. The public transport systems in Munich include 275 miles of S-Bahn (suburban trains), 59 miles of U-Bahn (underground trains), 49 miles of tram, and 282 miles of local bus route. The systems are operated by different organizations under the supervision of the Munich Transport and Tariff Association (MVV_Münchner Verkehrs und Tarifverbund). In 2011, public transport systems in Munich transport 522 million passengers. Sixty-six per cent of the residents of Munich use the underground, bus, and tram several times per week, and 35 percent of them are daily user of the systems (Münchner Verkehrsgesellschaft 2010).

A city of 1.3 million inhabitants, of which more than 300,000 commute each day, and with about 5 million visitors every year, Munich is facing increasing problems in traffic management (Thierstein and Reiss-Schmidt 2008). This is especially so when among the 300,000 
work commuters, only about 48 percent are public transport users. In addition, more than 500,000 cars cross the city boundaries daily, and this number is expected to have increased a further 30 percent by 2015. Consequently, without appropriate integrated policy intervention, increasing congestion, noise, and air pollution will be inevitable in Munich.

Since the early 20th century, the city of Munich has placed importance in urban planning and transport management. Several transport projects and development plans have been undertaken in Munich, including Perspective Munich, which was initiated in 1998 aiming at better urban expansion management (City of Munich 2005a, 2005b). With the motto "Compact, Urban, Green," Perspective Munich is a flexible guide founded on two principles: sustainability and urbanism. The city invested one million euros per year to implement the mobility management concept "München-Gscheid mobil," targeting increased (sustainable) mobility for four groups: new citizens, children and young people, companies, and other important target groups including older adults (Schreiner 2007). Several efforts have been made to build up a sustainable mobility in the metropolitan region of Munich; however, the tourist user group so far has been neglected.

While the majority of users of public transport are local residents, tourists also benefit from the system. Munich has tremendous appeal to tourists, and the provision of excellent public transport services is necessary to support the growing number of tourists while simultaneously contributing to environmental goals (Münchner Verkehrsgesellshaft 2010). An important component of this is a greater understanding of tourist demands, expectations, and satisfaction with public transport in Munich.

\section{Methodology}

To examine tourist use and satisfaction with public transport in Munich, data were collected from a visitor survey. Questionnaire-based surveys are a standard method to research customer behavior (see, for example, Bansal and Eiselt 2004, Fellesson and Friman 2008) and are also adopted in this study. Due to time and labor constraints, self-administered surveys were used.

\section{Questionnaire Design}

Respondents were filtered by the question "Have you used public transport in Munich during this visit?" Users of public transport were then asked to indicate their level of satisfaction with 16 service aspects of public transport in Munich. This list of attributes was developed with reference to the literature review above. A five-point Likert scale was used ( $1=$ very dissatisfied to $5=$ very satisfied). This question was preceded by the question, "In general, how satisfied are you with public transport in Munich?" to examine whether tourist satisfaction with particular service dimensions is correlated with their satisfaction with the total service as a whole.

\section{Data Collection}

To generate the largest number possible of respondents, the survey was carried out at the most popular tourist sites in Munich. The top 10 attractions in Munich (according to tourist information websites) were all considered as survey sites. Site examination and pre-tests resulted in three main study sites: the English Garden, the Residenz, and the 
Pinakothek Museums. These are sites that are both popular with tourists and convenient for approaching them. The survey assistants (three in total) divided their time among these sites.

Respondents were recruited using a random intercept approach. The survey assistant approached the tourists near the entrance of the attraction, introducing herself, briefly outlining the research project, and inviting the tourists to participate in the survey. Questionnaires were handed out to those who had agreed to participate.

Following pilot testing, the survey was conducted in April and May 2012. Overall, 2,481 people were approached and about 500 questionnaires were distributed. Of the 483 questionnaires collected, 466 were usable and 17 were rejected because the questionnaire was not properly completed, most of the important questions were skipped, or the respondents were not considered as tourists.

\section{Data Analysis}

Data were analyzed in three steps. First, tourists' levels of satisfaction with each service aspect were compared by means, median, and mode. Second, principle component analysis with the Varimax orthogonal rotation method was adopted to delineate the underlying dimensions that were associated with the satisfaction with public transport in Munich. Factors were extracted using the following criteria: an eigenvalue greater than 1 and factor loadings greater than 0.5 . A reliability analysis (Cronbach's alpha) was used to assess the correlation between variables of each identified factor. All factors with an $\alpha$ reliability above 0.50 were accepted for the purpose of this study. Third, Discriminant Function Analysis (stepwise method) was run to identify the most important factors influencing the tourists' satisfaction with public transport in Munich. This step has been proven as effective in identifying predictors of customer satisfaction in previous studies (Kim and Lee 2011; Fellesson and Friman 2008).

\section{Findings}

\section{Respondents' Profile}

The survey sample includes 466 respondents, of which 82 percent ( 380 visitors) have used public transport in Munich during their visit. As shown in Table 1, around half of the respondents were female, and the majority (40\%) were ages 18-29. Most public transport users are well-educated ( $48 \%$ university/college graduates and $14 \%$ post-graduates). Germans were the largest group of visitors (21\%), and all other European visitors represent 51 percent. A majority of users ( $87 \%)$ indicated no health restrictions. Almost half of the sample (48\%) had previously been to Munich. A stay of 2-3 days is most common (41\%), followed by $4-6$ days (32\%). Most visitors traveled with their friends (31\%), partner (23\%), and family or relatives (22\%). The majority of them visited Munich on holiday (54\%) or for VFR purposes (22\%). About 39 percent of the visitors stated rare or non-use of public transport, whereas 36 percent used public transport almost every day at their home residences. Most of the respondents possessed a valid driver license (93\%), and 77 percent indicated ownership of a car. 
TABLE 1.

Respondent Profile

\begin{tabular}{|c|c|c|c|c|c|}
\hline Characteristics: Demographic & $\mathbf{n}$ & $\%$ & Characteristics: Trip Profile & $\mathbf{n}$ & $\%$ \\
\hline Gender & & & First time visitor in Munich & & \\
\hline Male & 192 & 50.4 & Yes & 184 & 48.4 \\
\hline Female & 188 & 49.6 & No & 196 & 51.6 \\
\hline Age & & & Trip duration & & \\
\hline$<18$ & 10 & 2.7 & One day & 37 & 9.7 \\
\hline $18-29$ & 151 & 39.7 & 2-3 days & 155 & 40.7 \\
\hline $30-39$ & 67 & 17.6 & $4-6$ days & 121 & 31.9 \\
\hline $40-54$ & 67 & 17.6 & 7-14 days & 52 & 13.7 \\
\hline $55-64$ & 62 & 16.3 & More than 14 days & 15 & 4.0 \\
\hline \multirow[t]{2}{*}{$65+$} & 23 & 6.1 & & & \\
\hline & & & Travel partner & & \\
\hline Educational level & & & Alone & 58 & 15.3 \\
\hline Secondary school & 33 & 8.8 & Friends & 118 & 31.1 \\
\hline High school & 75 & 19.8 & Partner & 86 & 22.7 \\
\hline Vocational school & 27 & 7.2 & Family or relatives & 83 & 21.9 \\
\hline College and University & 182 & 47.9 & Colleagues & 33 & 8.7 \\
\hline Post graduate & 55 & 14.4 & Other & 1 & 0.3 \\
\hline \multirow[t]{2}{*}{ Other } & 7 & 1.9 & & & \\
\hline & & & Main purpose of the trip & & \\
\hline Country of residence & & & VFR & 84 & 22.0 \\
\hline Germany & 80 & 21.1 & Business & 39 & 10.3 \\
\hline Other European countries & 195 & 51.2 & Holiday & 204 & 53.7 \\
\hline U.S. and Canada & 78 & 12.5 & Education & 35 & 9.3 \\
\hline Other parts of North America & 16 & 4.3 & Other & 18 & 4.8 \\
\hline Oceania & 6 & 1.6 & & & \\
\hline \multirow[t]{2}{*}{ Asia } & 4 & 9.3 & Use of public transport at home & & \\
\hline & & & Almost every day & 138 & 36.4 \\
\hline Health restriction & & & Once or twice per week & 93 & 24.6 \\
\hline Sight & 24 & 6.3 & Rarely or never & 148 & 39.0 \\
\hline Walking & 10 & 2.7 & & & \\
\hline Hearing & 7 & 1.8 & Driver license ownership & & \\
\hline No restriction & 332 & 87.4 & Yes & 352 & 92.5 \\
\hline \multirow[t]{4}{*}{ More than one restriction } & 7 & 1.8 & No & 28 & 7.5 \\
\hline & & & Car ownership & & \\
\hline & & & Yes & 293 & 77.2 \\
\hline & & & No & 87 & 22.8 \\
\hline
\end{tabular}




\section{Tourist Use of Public Transport in Munich}

As expected, public transport was mainly used for tourism-related purposes such as to get to attractions (77\% of total respondents) or to travel around Munich for an overview of the city (54\%). Tourists also used public transport for shopping (47\%), visiting friends and relatives (21\%), and business-related purposes (13\%). The majority of the sample (51\%) tended to use public transport for all their trips made in the city, compared to 11 percent who had used public transport in Munich only once. The U-Bahn (underground train) appeared to be the most popular public transport mode (used by $88 \%$ of respondents), followed by S-Bahn (suburban train) (67\%). Other types (tram and bus) are relatively less common ( $43 \%$ and $39 \%$, respectively).

The most popular tickets used by tourists are the partner-day ticket (29\%), followed by three-day ticket (27\%), single-day ticket (20\%), and single-trip ticket (18\%). Other types of tickets, such as a weekly ticket, a monthly ticket, and a Bavaria ticket (allows a single person or a group of up to five to use unlimited regional public transport in Bavaria for one day), were only used by fewer than 10 percent of the respondents. Interestingly, the CityTourCard, a combination ticket that includes travel by public transport and discounts for several tourist attractions, was only used by around 5 percent of the respondents.

\section{Visitor's Satisfaction with Public Transport in Munich}

Respondents were asked to indicate how satisfied they were with public transport with regard to 16 service dimensions. Table 2 illustrates a comparison of the service items by means, median and mode (in descending order by means). Visitors tended to be satisfied with most service aspects of public transport in Munich, as indicated by the fact that almost all items (except ticket price) have a score above 3.0 (neither dissatisfied nor satisfied). Characteristics of public transport in Munich that were highly appreciated $(M>=4.00$, somewhat satisfied) include punctuality, reliability, network connection, and service frequency. Items received lowest scores are staff service, comfort while waiting at bus stops or train stations, and ticket price. These items were also most mentioned in visitors' comments and suggestions for service improvement. 
TABLE 2.

Visitor Satisfaction with Service Aspects Compare Means

\begin{tabular}{|l|c|c|c|c|}
\hline \multicolumn{1}{|c|}{ Service Aspect } & Mean & Median & Mode & SD \\
\hline Punctuality & 4.21 & 4 & 4 & 0.867 \\
\hline Reliability & 4.19 & 4 & 4 & 0.845 \\
\hline Network connection & 4.11 & 4 & 4 & 0.823 \\
\hline Service frequency & 4.00 & 4 & 4 & 0.913 \\
\hline Convenience of time schedule & 3.98 & 4 & 4 & 0.869 \\
\hline Accessibility of train stations and bus stops & 3.96 & 4 & 4 & 0.830 \\
\hline Accessibility of vehicles & 3.95 & 4 & 4 & 0.861 \\
\hline Safety on board & 3.87 & 4 & 4 & 0.890 \\
\hline Ease-of-use & 3.87 & 4 & 4 & 0.721 \\
\hline Information & 3.85 & 4 & 4 & 0.905 \\
\hline Cleanliness of vehicle & 3.67 & 4 & 4 & 0.978 \\
\hline Space on vehicle & 3.66 & 4 & 4 & 0.921 \\
\hline Seat availability & 3.55 & 4 & 4 & 0.916 \\
\hline Staff service & 3.49 & 3 & 3 & 0.960 \\
\hline Comfort while waiting at bus stops or train stations & 3.44 & 3 & 3 & 0.892 \\
\hline Ticket price & 2.93 & 3 & 3 & 1.158 \\
\hline Satisfaction in general & 4.68 & 4 & 4 & 0.694 \\
\hline
\end{tabular}

In addition to detailed assessment of satisfaction with specific aspects of the public transport services, respondents were asked to rank their overall satisfaction. Findings indicated a high level of satisfaction with public transport in Munich, with a mean score of 4.08 and mode of 4.0 .

The 16 service dimensions were subjected to factor analysis using SPSS 16.0, which resulted in four factors, explaining 66.4 percent of the total variance (Table 3). Each factor was labeled according to the appropriateness of individual items it included. 
TABLE 3.

Factor Analysis of Public Transport Service Dimensions

\begin{tabular}{|c|c|c|c|c|}
\hline Service Aspect & Factor 1 & Factor 2 & Factor 3 & Factor 4 \\
\hline \multicolumn{5}{|l|}{ Traveling comfort } \\
\hline Space on vehicle & 0.835 & & & \\
\hline Cleanliness of the vehicle & 0.788 & & & \\
\hline Seat availability & 0.776 & & & \\
\hline Comfort while waiting at bus stops or train stations & 0.736 & & & \\
\hline Safety on board & 0.701 & & & \\
\hline \multicolumn{5}{|l|}{ Service quality } \\
\hline Punctuality & & 0.803 & & \\
\hline Reliability & & 0.799 & & \\
\hline Service frequency & & 0.698 & & \\
\hline Convenience of time schedule & & 0.619 & & \\
\hline Network connection & & 0.598 & & \\
\hline \multicolumn{5}{|l|}{ Accessibility } \\
\hline Accessibility of train stations and bus stops & & & 0.820 & \\
\hline Accessibility of vehicles & & & 0.676 & \\
\hline \multicolumn{5}{|l|}{ Additional features } \\
\hline Ticket price & & & & 0.712 \\
\hline Ease of use & & & & 0.656 \\
\hline Staff service & & & & 0.636 \\
\hline Information & & & & 0.90 \\
\hline Eigenvalue & 3.48 & 3.02 & 2.10 & 2.02 \\
\hline Variance (\%) & 21.77 & 18.85 & 13.07 & 12.62 \\
\hline Cumulative variance (\%) & 21.77 & 40.62 & 53.67 & 66.31 \\
\hline Reliability coefficient & 0.87 & 0.86 & 0.82 & 0.67 \\
\hline
\end{tabular}

Factor 1, Traveling Comfort ( $\alpha=0.87)$, explains 21.8 percent of the variance. It includes five variables (space on vehicle, cleanliness of the vehicle, seat availability, comfort while waiting at bus stops or train stations, and safety on board) and reflects the importance of the conditions and facilities of the vehicles and stations. As expected, visitors demonstrated a strong preference for traveling comfortably. The second factor $(\alpha=0.86$ ) includes five items (punctuality, reliability, service frequency, convenience of the time schedule, and network connection). It describes different service aspects of the public transport system and therefore was labeled Service Quality. It explains 18.9 percent of the total variance. The third factor $(\alpha=0.82)$ includes two aspects indicating the accessibility of the train stations, bus stops, and vehicles. The factor explains 13.1 percent the total variance. The fourth factor $(\alpha=0.67)$ includes ticket price, ease-of-use, staff service, and information and explains 12.6 percent of the total variance.

These four aspects first appeared to be quite different from each other. On the other hand, they are also very distinctive from the other three factors. It can be seen that all these aspects describe additional features/benefits of the public transport system, which are highly valued by visitors and, hence, was labeled Additional Features. 


\section{Factors Influencing Visitor Satisfaction with Public Transport}

\section{Satisfaction with Public Transport: Comparisons between Different Groups}

The relationship between satisfaction with public transport and other variables was investigated using the Spearman Test. The results show that satisfaction with public transport was independent from most variables (demographic and trip-related characteristics) except for country of residence. There is a slight connection between tourists' country of residence and their satisfaction with public transport $\left(r_{s}=0.128\right)$. Asians and visitors from the U.S. and Canada tended to be more satisfied; German and other European visitors were more critical in comparison.

\section{Predictor of Satisfaction}

Public transport performance was evaluated in multiple aspects. However, the influences of these aspects to the overall satisfaction differ from each other. Identifying the most influential service aspects is important for service improvement. To determine which individual service aspect has the strongest influence on tourists' overall satisfaction, a Discriminant Function Analysis was performed (with "overall satisfaction with public transport" as the grouping variable and the independent variables are 16 specific service dimension evaluation). Six items were revealed as being most important to visitor satisfaction with public transport: information, ticket price, service frequency, space on the vehicle, cleanliness of the vehicle, and ease of use (Table 4).

TABLE 4.

Results of Discriminant Function Analysis a,b,c,d

\begin{tabular}{|c|c|c|c|c|c|c|c|c|c|c|c|c|c|}
\hline \multirow{3}{*}{ Step } & \multirow{3}{*}{ Entered } & \multicolumn{12}{|c|}{ Wilks' Lambda } \\
\hline & & \multirow{2}{*}{ Statistic } & \multirow{2}{*}{$d f 1$} & \multirow{2}{*}{$d f 2$} & \multirow{2}{*}{$d f 3$} & \multicolumn{4}{|c|}{ Exact $F$} & \multicolumn{4}{|c|}{ Approximate $F$} \\
\hline & & & & & & Statistic & $d f 1$ & $d f 2$ & Sig. & Statistic & $d f 1$ & $d f 2$ & Sig. \\
\hline 1 & Information & 0.724 & 1 & 4 & 334.000 & 31.802 & 4 & 334.000 & .000 & & & & \\
\hline 2 & Cleanliness of vehicle & 0.601 & 2 & 4 & 334.000 & 24.158 & 8 & 666.000 & .000 & & & & \\
\hline 3 & Service frequency & 0.540 & 3 & 4 & 334.000 & & & & & 19.225 & 12 & 878.681 & 0.000 \\
\hline 4 & Ease of use & 0.510 & 4 & 4 & 334.000 & & & & & 15.593 & 16 & $1.012 \mathrm{E} 3$ & 0.000 \\
\hline 5 & Space on vehicle & 0.492 & 5 & 4 & 334.000 & & & & & 13.055 & 20 & $1.095 \mathrm{E} 3$ & 0.000 \\
\hline 6 & Ticket price & 0.475 & 6 & 4 & 334.000 & & & & & 11.375 & 24 & 1.149E3 & 0.000 \\
\hline
\end{tabular}

At each step, variable that minimizes overall Wilks' Lambda is entered.

${ }^{a}$ Maximum number of steps is 32 .

${ }^{b}$ Maximum significance of $F$ to enter is 0.05 .

'Minimum significance of $F$ to remove is 0.10 .

${ }^{d} \mathrm{~F}$ level, tolerance, or VIN insufficient for further computation. 


\section{Discussion and Conclusions Improving Public Transport Services}

\section{Public Transport Service Dimensions}

As discussed earlier several dimensions of public transport service have been identified in the literature. In this study, four service dimensions were found: traveling comfort, service quality, accessibility, and additional features. Each of these dimensions comprises at least two individual interrelated service aspects. Collectively, the four dimensions explain 66.4 percent of the total variance. A comparison of the present findings with those of previous studies shows some similarities as well as differences (Table 5).

TABLE 5.

Public Transport Service Dimensions Identified

\begin{tabular}{|l|l|}
\hline \multicolumn{1}{|c|}{ Author(s) } & \multicolumn{1}{c|}{ Service Dimensions } \\
\hline Budiono (2009) & Soft quality, functionality quality \\
\hline $\begin{array}{l}\text { Fellesson and } \\
\text { Friman (2008) }\end{array}$ & Systems, comfort, staff, safety \\
\hline $\begin{array}{l}\text { Thompson and } \\
\text { Schofield (2007) }\end{array}$ & Ease-of-use, efficiency and safety, good parking \\
\hline $\begin{array}{l}\text { Tyrinopoulos and } \\
\text { Antoniou (2008) }\end{array}$ & Quality of service, transfer quality, service production, information/ courtesy \\
\hline This Study & Traveling comfort, service quality, accessibility, additional features \\
\hline
\end{tabular}

As with Fellesson and Friman (2008), this study identified traveling comfort as an important service dimension. This factor describes features needed for a comfortable trip. It covers the requirements for vehicles (space, cleanliness, seat availability, and safety) as well as stations.

Service quality is another significant dimension of public transport performance, which was also explored in earlier studies (Budiono 2009; Tyrinopoulos and Antoniou 2008). Visitors appreciate an effective and efficient system with high punctuality and reliability, frequent services, convenient schedule, and good network connection.

Additional features shared some similarities with Tyrinopoulos and Antoniou's (2008) identification of information/courtesy, Thompson and Schofield's (2007) ease of use, and Fellesson and Friman's (2008) staff dimensions.

Accessibility is the new dimension found in this study, which was not examined in previous research. Accessibility is an important criterion for high-quality, sustainable public transport systems (Soltani et al. 2012; Gutiérrez 2009). Accessible stations and transport vehicles are necessary for the improvement of customer penetration.

\section{Most Important Service Aspects Influencing Overall Satisfaction}

In conclusion, visitors in Munich were relatively satisfied with the public transport services. However, there is still room for service enhancement. The six most important attributes were identified, which include both new aspects and those previously found in studies of local users. Improvement of public transport system in Munich should focus on these six key aspects, as discussed below. 
1. Information is recognized as very important for visitors when using public transport (Friman, Edvardsson, and Gärling 2001; Friman and Gärling 2001). According to Thompson (2004), tourists require more information than residents. One reason could be much transport information is linked to local knowledge (e.g., train station location, departure and arrival points), whereas tourists are unfamiliar with the place and the systems. Second, there are differences in terms of information sources referred. Real-time information was considered most important by local public transport users (Molin and Timmermans 2006). Conversely, tourists tend to rely on traditional information sources such as a tourist information center, word-ofmouth, attraction leaflets, the Internet, and hotel reception (Thompson 2004). In this study, train stations and bus stops, the Internet, local people, accommodation receptions, and tourist information centers were found to be the most common sources. Language is also another problem indicated in the survey. Many nonGerman-speaking tourists suggested that English information was either unavailable or insufficient. Public transport providers should cooperate with tourist centers, tourist attractions, and hotels to give tourists accurate and updated information. More information in English should be offered.

2. Ticket price has a major influence on the attractiveness of public transport (Redman et al. 2013; Budiono 2009). Fare promotion and special ticket schemes have proven positive in the case of encouraging local residents to use public transport. The same method could be applied to tourists. A considerable number of negative comments from respondents were related to ticket prices. Compared to other European cities, ticket prices for public transport in Munich are relatively high. The ticketing system was also perceived as complicated and difficult to use. Therefore, it is essential that the types of tickets and ticket zones be presented in a clear and simple way. Electronic smart ticketing systems should also be a topic for future planning.

3. Service frequency is a major factor to customer satisfaction with public transport, and this aspect consistently appeared in studies on public transport service assessment (Budiono 2009; Del Castillo and Benitez 2012; Tyrinopoulos and Antoniou 2008; Redman et al. 2013). While Munich has an extensive transport network, public transport does not run very frequently, especially during off-peak hours. (The U-Bahn runs every 10 minutes and and the S-Bahn runs every 20 minutes.) Increasing service frequency is believed to stimulate ridership (Wall and McDonald 2007). However, the decision of increasing services might be affected by several factors, including finance and budget. On the other hand, providing more services in major tourist routes could be one possible solution.

4. Ease of use of a public transportation system is essential for passengers (Dziekan 2003; Redman et al. 2013; Thompson and Schofield 2007). Thompson and Schofield (2008) suggested ease of use is more important for visitors than efficiency and safety. In this study, respondents were relatively satisfied with the public transport ease of use (mean=3.87 and mode $=4$ ). Spearman correlation tests show that visitors' perception of ease of use is independent from most descriptive variables (demographic and trip-related variables) and is slightly related to the following variables: 
- First time visitor to Munich $\left(r_{s}=0.156\right)$ : As expected, returning visitors found public transport easier to use compared to first-time visitors. Similarly, the number of previous trips also has a positive effect on visitors' perception $\left(r_{s}=0.153\right)$.

- Frequency of public transport use in Munich $\left(r_{s}=0.129\right)$ : The more often respondents used public transport during their visit, the easier they thought it was to use the system.

- Valid driver license ownership ( $\left.r_{s}=-0.131\right)$ : Respondents who owned a driver license tended to find public transport easier to use compared to those who did not.

- Recommend to use $\left(r_{s}=-0.106\right)$ : Visitors tended to recommend others to use public transport if public transport was perceived as "easy." However, it is noted that the number of respondents who did not recommend others to use public transport was small (9 respondents).

- Improving ease of use is also related to information and ticketing system improvement. As discussed, more information in English and clear ticketing systems are essential to make public transport in Munich easier for visitors to use.

5/6. Comfort attributes are revealed as important for visitors traveling by public transport, in line with findings from Redman et al. (2013). In particular, areas should also receive more attention are the vehicle's cleanliness and space. Clean and more spacious (i.e., less crowded) buses and trains are desirable. Upgrading of the waiting area at train stations and bus stops should also be noted. Providing more seats for passengers while waiting for their trains or buses is recommended.

\section{Implications for Future Research}

Transport is an essential element in tourism systems, and public transport plays a vital role in sustainable tourism development. However, there is little information on tourist use of public transport at destinations. This paper contributes to the understanding of tourist satisfaction with public transport and the factors that influence their perception. Four service dimensions were identified: traveling comfort, service quality, accessibility, and additional features. In line with findings from Thompson and Schofield (2007), dimensions of public transport services identified in this study suggest considerable resemblance to research on local users.

Public transport services in Munich were positively evaluated by tourists, and their perceptions are independent from most factors. Visitors were most satisfied with system punctuality, reliability, network connection, and service frequency. On the other hand, ticket price received the lowest rating and were perceived as "expensive" and "complicated." Improvement of waiting facilities at bus stops and train stations is essential. Other areas that need further attention include staff service, seat availability, space, and cleanliness of the vehicle.

Though carefully planned and conducted, this study is not without limitations. First, most study sites are centrally located and relatively easy to access by public transport. More respondents in remote tourist attractions would have provided a better picture of tourist 
perception. Second, as with all self-completed surveys, some respondents might not have answered the questionnaire carefully or understood the questions correctly. In addition, more open-ended questions would have provided useful further information in tourist behavior.

Despite these limitations, the paper has shed light on the use of public transport by tourists. Improving customer satisfaction is vital to the future development of public transport. Further studies are necessary to better understand tourist behavior and improve their experience with public transport, especially as such research may not only bring economic returns to a destination but also contribute to sustainable transport goals.

\section{References}

Abou-Zeid, Maya, Regina Witter, Michel Bierlaire, Vincent Kaufmann, and Moshe BenAkiva. 2012. Happiness and travel mode switching: Findings from a Swiss public transportation experiment. Transport Policy 19 (1): 93-104.

Bansal, $\mathrm{H}_{\text {., }}$ and H. A. Eiselt. 2004. Exploratory research of tourist motivations and planning. Tourism Management 25(3): 387-396.

Budiono, Oktiani Astuti. 2009. Customer satisfaction in public bus transportation: A study of travelers' perception in Indonesia. Master thesis, Karlstad University.

Cantwell, Mairead, Brian Caulfield, and Margaret O'Mahony. 2009. Examining the factors that impact public transport commuting satisfaction. Journal of Public Transportation 12(2): 1-21.

City of Munich. 2005a. Shaping the future of Munich, Perspective Munich-Strategies, Principles, Projects. Development Report 2005. Munich: Department of Urban Planning and Building Regulation.

City of Munich. 2005b.Transport Development Plan, Perspective Munich. Development Report 2005. Munich: Department of Urban Planning and Building Regulation.

Dallen, Jamie. 2007. The challenges of diverse visitor perceptions: Rail policy and sustainable transport at the resort destination. Journal of Transport Geography 15(2): 104-115.

Del Castillo, J. M., and Francisco G. Benitez. 2012. A methodology for modeling and identifying users satisfaction issues in public transport systems based on users surveys. Procedia-Social and Behavioral Sciences 54(0): 1104-1114. doi: http://dx.doi. org/10.1016/j.sbspro.2012.09.825.

Diana, Marco. 2012. Measuring the satisfaction of multimodal travelers for local transit services in different urban contexts. Transportation Research Part A: Policy and Practice 46(1): 1-11.

Dickinson, Janet E., Derek Robbins, and John Fletcher. 2009. Representation of transport: A rural destination analysis. Annals of Tourism Research 36(1): 103-123. doi: 10.1016/j. annals.2008.10.005. 
Duval, David Timothy. 2007. Tourism and Transport: Modes, Networks and Flow. Clevedon; Buffalo: Channel View Publications.

Dziekan, Katrin. 2003. Easy to use public transport-Framework for analysis and development of simplicity, information and orientation. Division of Transport and Logistics, KTH Royal Institute of Technology, Stockholm.

Eboli, Laura, and Gabriella Mazzulla. 2007. Service quality attributes affecting customer satisfaction for bus transit. Journal of Public Transportation 10(3): 21-34.

Fellesson, Markus, and Margareta Friman. 2008. Perceived satisfaction with public transport service in nine european cities. Journal of the Transportation Research Forum 47(3): 93-104.

Friman, Margareta, Bo Edvardsson, and Tommy Gärling. 2001. Frequency of negative critical incidents and satisfaction with public transport services. I. Journal of Retailing and Consumer Services 8(2): 95-104. doi: http://dx.doi.org/10.1016/S0969-6989(00)00003-5.

Friman, Margareta, and Tommy Gärling. 2001. Frequency of negative critical incidents and satisfaction with public transport services. II. Journal of Retailing and Consumer Services 8(2): 105-114.

German National Tourist Board.2011. Incoming Tourism Germany. Retrieved October 12, 2012, from http://www.germany.travel/media/en/DZT_Incoming_GTM11_web.pdf.

Gorter, Cees, Peter Nijkamp, and Rob Vork. 2000. Analysis of travelers' satisafction with transport chain. Transportation Planning and Technology 23: 237-258.

Gronau, Werner, and Andreas Kagermeier. 2007. Key factors for successful leisure and tourism public transport provision. Journal of Transport Geography 15(2): 127-135.

Guiver, Jo, Les Lumsdon, Richard Weston, and Maggie Ferguson. 2007. Do buses help meet tourism objectives? The contribution and potential of scheduled buses in rural destination areas. Transport Policy 14(4): 275-282. doi: 10.1016/j.tranpol.2007.02.006.

Gutiérrez, J. 2009. Transport and accessibility. In International Encyclopedia of Human Geography, Rob and Thrift Nigel, eds., 410-417. Oxford: Elsevier.

Gwilliam, Ken. 2008. A review of issues in transit economics. Research in Transportation Economics 23(1): 4-22. doi: http://dx.doi.org/10.1016/j.retrec.2008.10.002.

Kim, Yu Kyoung, and Hyung Ryong Lee. 2011. Customer satisfaction using low cost carriers. Tourism Management 32(2): 235-243. doi: 10.1016/j.tourman.2009.12.008.

Kinsella, James, and Brian Caulfield. 2011. An examination of the quality and ease-of-use of public transport in Dublin from a new comer's perspective. Journal of Public Transportation 14 (1): 69-81.

Kozak, Metin. 2001. Comparative assessment oftourist satisfaction with destinations across two nationalities. Tourism Management 22(4): 391-401.

Lai, Wen-Tai, and Ching-Fu Chen. 2011. Behavioral intentions of public transit passengers-The roles of service quality, perceived value, satisfaction and involvement. Transport Policy 18(2): 318-325. 
Litman, Todd. 2007. Evaluating rail transit benefits: A comment. Transport Policy 14(1): 94-97. doi: http://dx.doi.org/10.1016/j.tranpol.2006.09.003.

Litman, Todd. 2011. Evaluating public transit benefits and costs. Victoria Transport Policy Institute.

Lumsdon, Les, Paul Downward, and Steven Rhoden. 2006. Transport for tourism: Can public transport encourage a modal shift in the day visitor market? Journal of Sustainable Tourism 14(2): 139-156. doi: 10.1080/09669580608669049.

Molin, Eric J. E., and Harry J. P. Timmermans. 2006. Traveler expectations and willingness-to-pay for Web-enabled public transport information services. Transportation Research Part C: Emerging Technologies 14(2): 57-67. doi: http://dx.doi.org/10.1016/j. trc.2006.05.003.

Münchner Verkehrsgesellschaft mbH (MVG). 2010. Sustainable mobility for Munich. Retrieved November 11, 2012, from http://www.mvg-mobil.de/en/images/mvg nachhaltigkeitsbericht_02052011_eng.pdf .

Page, S. J. 2011. Tourism Management, 4th ed. Oxford: Butterworth-Heinemann.

Redman, Lauren, Margareta Friman, Tommy Gärling, and Terry Hartig. 2013. Quality attributes of public transport that attract car users: A research review. Transport Policy 25(0): 119-127. doi: http://dx.doi.org/10.1016/j.tranpol.2012.11.005.

Regnerus, Hielke D., Raoul Beunen, and Catharinus F. Jaarsma. 2007. Recreational traffic management: The relations between research and implementation. Transport Policy 14(3): 258-267. doi: 10.1016/j.tranpol.2007.02.002.

Schreiner, Martin. 2007. „München - gscheid mobil“: Munich invests 1 million $€ / a$ for realising new mobility management concept. Retrieved 15 March, 2013, from http:// www.kpvv.nl/files_content/schreiner.pdf

Soltani, Seyed Hassan Khalifeh, Mashita Sham, Mohamad Awang, and Rostam Yaman. 2012. Accessibility for disabled in public transportation terminal. Procedia-Social and Behavioral Sciences 35(0): 89-96. doi: http://dx.doi.org/10.1016/j.sbspro.2012.02.066.

Song, Haiyan, Robert van der Veen, Gang Li, and Jason L. Chen. 2012. The Hong Kong tourist satisfaction index. Annals of Tourism Research 39(1): 459-479.

Stradling, Stephen, Michael Carreno, Tom Rye, and Allyson Noble. 2007. Passenger perceptions and the ideal urban bus journey experience. Transport Policy 14(4): 283-292. doi: 10.1016/j.tranpol.2007.02.003.

Thierstein, Alain, and Stephan Reiss-Schmidt. 2008. Urban development management in Munich, Germany. In 44th ISOCARP Congress.

Thompson, Karen. 2004. Tourists' use of public transportation information: What they need and what they get. Paper read at Association for European Transport, 04/10/2004-06/10/2004, Strasbourg, France. 
Thompson, Karen, and Peter Schofield. 2007. An investigation of the relationship between public transport performance and destination satisfaction. Journal of Transport Geography 15(2): 136-144.

Tribe, John, and Tim Snaith. 1998. From SERVQUAL to HOLSAT: Holiday satisfaction in Varadero, Cuba. Tourism Management 19(1): 25-34. doi: http://dx.doi.org/10.1016/ S0261-5177(97)00094-0.

Tyrinopoulos, Yannis, and Constantinos Antoniou. 2008. Public transit user satisfaction: Variability and policy implications. Transport Policy 15(4): 260-272.

Wall, Graham, and Mike McDonald. 2007. Improving bus service quality and information in Winchester. Transport Policy 14(2): 165-179. doi: 10.1016/j.tranpol.2006.12.001.

\section{Acknowledgment}

This study was funded by the Hans-Böckler-Stiftung through the research project "Sustainable Mobility in the Metropolitan Region of Munich, Germany."

\section{About the Authors}

Diem-TRINH LE-KLÄHN (diemtrinh.le@tum.de) is a doctoral candidate at the School of Management, Technische Universität München, Germany. She is also a member of the mobil.LAB research group "Sustainable Mobility in the Metropolitan Region of Munich" at the Department of Urban Structure and Transport Planning. Her research focuses on sustainable tourism mobility at destinations.

C. Michael Hall (michael.hall@canterbury.ac.nz) is a Professor in Marketing at the Department of Management, University of Canterbury, New Zealand. He has a wide range of interests in tourism and human mobility, regional development, and social and destination marketing, especially in the context of environmental change.

REGINE GeRIKe (regine.gerike@boku.ac.at) chairs the Institute for Transport Studies at the University of Natural Resources and Life Sciences (BOKU) in Vienna, Austria. Her research interests include all aspects of transport ecology and economy, including modeling of environmental effects, empirical research, and holistic approaches to evaluating sustainable mobility. 